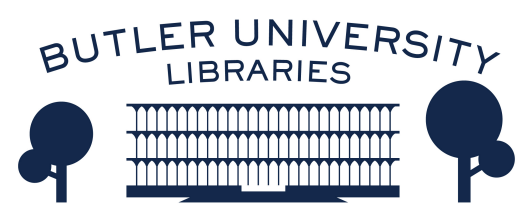

Journal of Hindu-Christian Studies

Volume 23

Article 23

January 2010

\title{
Book Review: "Hermeneutics and Hindu Thought: Toward a Fusion of Horizons"
}

Brian K. Pennington

Follow this and additional works at: https://digitalcommons.butler.edu/jhcs

Part of the Religion Commons

\section{Recommended Citation}

Pennington, Brian K. (2010) "Book Review: "Hermeneutics and Hindu Thought: Toward a Fusion of Horizons"," Journal of Hindu-Christian Studies: Vol. 23, Article 23.

Available at: https://doi.org/10.7825/2164-6279.1475

The Journal of Hindu-Christian Studies is a publication of the Society for Hindu-Christian Studies. The digital version is made available by Digital Commons @ Butler University. For questions about the Journal or the Society, please contact cbauman@butler.edu. For more information about Digital Commons @ Butler University, please contact digitalscholarship@butler.edu. 
Like all books, Beyond Boundaries is imperfect. Its origins as a doctoral thesis (at the University of Madras's well-respected Department of Christian Studies) are overly evident at times, and the text as a whole is too lightly edited. Moreover, the book assumes an audience already somewhat familiar with BCCs (I, unfortunately, was not); no formal definition of the term is given for over a hundred pages. The book also reads, in certain passages, as if it is part of an internal Catholic conversationDavid is a member of the Carmelite Order and a native of the district-and at times the BCCs under investigation seem to be judged by how well they conform to certain assumed but largely unstated ideals.

More problematic, however, is the structure of the main thesis. The author argues that the anbiangal display a significant and increasing degree of tolerance for and engagement with Hindus and Hinduism (one of the assumed ideals), and should therefore be more intentionally and systematically used by the church hierarchy to promote interreligious harmony. That may in fact be true; but the evidence given to support the assertion comes entirely from an analysis of the BCCs. No comparative investigation of attitudes among Catholics more generally was done (or referenced) to demonstrate whether the tolerance and engagement displayed by the anbiangal was unique to them or merely a reflection of changing norms and perspectives in the Catholic Church more generally (or at least among lay Indian Catholics). In fact, at various points the testimonies cited by the author suggest that the most significant factor in the emergence of more tolerant attitudes about Hinduism was not the formation of the BCCs, but rather the declining influence of missionaries and of an older generation of priests who tended to disparage Hinduism and discourage Christian participation in Hindu festivals and rituals. That said, it is not my intention to contradict the author's findings-he may, and even quite likely is, correct-but rather to indicate that the argument could have been made more persuasively.

Despite these minor issues, Beyond Boundaries is a worthwhile, thoughtful, and provocative read, and would be particularly appealing to scholars or students of Indian Catholicism/Christianity, those who conduct research on Hindu-Christian conflict, and Catholic leaders interested in new ways of "being Church."

Chad M. Bauman

Butler University

\section{Hermeneutics and Hindu Thought: Toward a Fusion of Horizons. Edited by Rita Sherma and Arvind Sharma. N.p.: Springer, 2008, 249 pp.}

THIS collection of eleven essays plus a set of responses by Sharma was initially inspired by a 2003 panel on Hindu philosophy and hermeneutics at the American Academy of Religion Annual Meeting. Some of its individual pieces are critical, historical, or analytical in nature, and others are constructive, but all address the relative absence of a truly dialogic encounter between the philosophical traditions of Hinduism and those of the West. As Rita Sherma's introduction to the volume puts it, these essays examiné
1) The challenges and possibilities inherent in the application of Western hermeneutics to the study of Hindu traditions; 2) Critiques of certain heuristics used to "understand" Hindu traditions in the past; 3) The elicitation of new hermeneutical paradigms from the Hindu texts and traditions, in order to develop cross-cultural or dialogical hermeneutics,(1).

Sherma's fine introductory essay traces the history of hermeneutics in the West from Schleiermacher through Dilthey, Heidegger, 
Gadamer and Ricouer, and then suggests sources for the discernment of a Hindu hermeneutical tradition, including the Vedas, the Gita, and bhasya (commentarial) literature. The presence of two distinct kinds of essays detracts somewhat from the unity of the volume, but given the emergent nature of the subject matter, a collection of pieces which explores the promise of an cross-fertilization of Hinduism and hermeneutics certainly moves the discussion forward substantially and must be regarded as a significant contribution to the fields of crosscultural philosophy and theology.

One group of essays is constructive in nature. These chapters examine the intersection of hermeneutics and the Hindu tradition with the aim of developing and promoting a particular strain of Hindu theology and/or practice. Given the commanding presence of Gadamer in the field of hermeneutics, it is not surprising that these constructive pieces do not advocate any sectarian Hindu ideology but promote, rather, non-exclusionary theologies that deliberately and self-consciously remain open, to further transformation in their encounter with the other. Klaus Klostermaier's essay argues for an encounter with "the Hindu center," his term for the awareness of the abyss of the ultimate that comes through meditation. An orientation toward this center, he maintains, can provide the samsara-like hermeneutical circle a fixed point and promote a deeper understanding of the other. By merging insights of process theology and Advaita Vedanta, Jeff Long advances a proposal for "the full development of Hinduism as a world religion," that is, one that is universally relevant, pluralistic in its nature, and open to all who elect it. Long's piece reads as something of a prolegomena to a fuller explication of a Hindu theology that realizes the global aspirations announced in the project of modern Hinduism imagined by Dayananda, Ramakrishna, Aurobindo, and Gandhi, a project which, as his title makes clear, he believes remains incomplete. Shrinivas Tilak suggests a reconceptualization of Indic religious traditions in terms of "caturdharmya," a concept he borrows from Arvind Sharma to characterize their innate ethical pluralism. In a more philosophical and less theological vein, Stephen
H. Phillips argues that, while Indological hermeneutics attends to intellectual and material history, philosophical hermeneutics, by contrast, must prioritize the search for what is true independent of culture and historical context, factors which should assume a secondary importance.

A second group of essays is historical and/or critical in their approach to hermeneutics. Most in this category examine the shortcomings of Western interpretive frameworks for analyzing Hindu or Indic materials. Arvind Sharma critiques the Christian monotheistic logic underlying the census's conception of religious identity that expects a person to have only one religion. Sharada Sugirtharaja demonstrates that Max Müller's interpretation of the Veda was tainted by his complicity in the imperial project and his Protestant biases. In his examination of the Mahabharata's Karna, Aditya Adarkar shows how hermeneutical paradigms for appreciating the distinctive nature of the heroic in the Indian epic tradition may lie within the Sanskrit sources themselves, but that they emerge most clearly when put in conversation with a Freudian framework derived from Western literary hermeneutics. In response to the flawed Western hermeneutics that found no moral philosophy in the Hindu tradition, T. S. Rukmani analyzes the Upanisads to argue that norms for individual ethical behavior are clearly present regardless of whether moksa or dharma is a text's highest motivating value.

In two of the volume's most technically dense essays, Purushottama Bilimoria and Leena Taneja place Western hermeneutical philosophers in sustained dialogue with schools of Hindu thought and practice to generate rich and nuanced models of cross-cultural hermeneutics. Emphasizing less Gadamer than Ricoeur and Heidegger as Gadamer's foils, Bilimoria undertakes a review of one strand of the West's analysis of the relationship between text and meaning and a briefer review of Mimamsa hermeneutics to demonstrate the possibilities for pursuing a radical (my word, not his) cross-cultural hermeneutics that creatively undermines tradition, authority, and the author. Taneja juxtaposes a fairly straightforward reading of Gadamer's analysis of the 
transformation that dialogue with an other engenders with the ontology of the self in Gaudiya Vaisnavism. Her comparison reveals how both traditions regard difference as fundamental to dialogue and full engagement with difference as the chief condition for transformation.

Arvind Sharma's careful responses to each of the papers is a nice addition to the volume, expanding the insights of each of the essays and demonstrating a cohesiveness to the volume that may not be evident on reading the individual essays themselves.

Hermeneutics and Hindu Thought takes no one paradigm for how a cross-cultural hermeneutics might or should take place as its standard. Its authors demonstrate, rather, that there is much promise in simply posing the question implied by the conjunction "and" in the book's title. That is to say, when one considers the range of projects that thinking about hermeneutics and Hindu thought together might generate, it is clear that there is a great deal of work that lies ahead as we begin to appreciate the tremendous resources for cross-cultural understanding that Indic traditions contain.

Brian K. Pennington

Maryville College

\section{Jesus in the Lotus: The Mystical Doorway between Christianity and Yogic Spirituality. Russill Paul. Novato, California: New World Library, 2009, 233 pp.}

Anyone interested in studying yoga theory and practice, its history from the time of Patañjali to today, its seeming endless variety of contemporary expressions and schools, will be hard pressed to keep up with the scholarly literature. The same cannot be said of the literature on the Christian encounter with yoga. Serious scholarship addressing the integration of yoga practice (especially aștānga yoga) and yoga philosophy into Christian spiritual praxis and theology is surprisingly rare, especially given the fact that thousands, perhaps millions of Christians today have taken up the practice of yoga. What is less rare are the many one-sided appraisals that either condemn or extol the merging of yoga and Christianity. Too often modern opinion treats yoga as a monolithic entity, often unaware of the complexity of yoga and its history. This simplistic approach, of course, makes it all too easy for Christian authors to argue their widely divergent positions.

Jesus in the Lotus: The Mystical Doorway between Christianity and Yogic Spirituality takes up the issue of yoga and Christianity in earnest fashion, but it is only partly successful in its approach, as it falls prey at times to a shifting understanding of what exactly yoga is. The author, Russill Paul, is a professional musician turned spiritual teacher and writer. Born and raised in India, he became a Benedictine monk under Bede Griffiths (d. 1993), the well-known Catholic monk and spiritual writer. After living five years at Father Bede's Saccidananda Ashram he left monastic life and carried to the West his master's legacy of "interspirituality" and his teaching about the complementarity of religions. For the past twenty years Paul has conducted numerous spirituality workshops and retreats, mostly in the U.S, as well as led spiritual pilgrimages back to his Indian homeland.

The author passionately advocates the incorporation of yoga into Christian praxis, for, he says, contemporary Christianity needs yoga to recover its mystical depth. Christians who practice yoga can "deepen their connection to God, other human beings, and creation as a whole." (5) Yoga can remedy the widespread tendency among Western Christians to think of divine transcendence as God's remote separation from creation. 'Yoga can restore a more nondualistic understanding of the divine-human and divine-world relationship, and it also can serve to reintroduce Christians to the sacredness of the body (30). What is remarkable about these 